\title{
Market Expansion Strategies for Turfgrass Producers in the Western United States
}

\author{
by
}

\author{
John J. Haydu, Alan W. Hodges and Loretta N. Satterthwaite \\ University of Florida, Food \& Resource Economics Department \\ Revised February 26, 2003
}

\section{Executive Summary}

This paper reports the results of the third and last phase of a turfgrass marketing study in the United States. The previous two phases of this study were conducted in the Eastern and Central United States. This research project was a joint effort by International Turfgrass Producers Foundation (ITPF) and the University of Florida's Institute of Food \& Agricultural Sciences. Each study consisted of two parts. In the first part, personal interviews were conducted with various sod-related businesses. The interview process identified critical factors influencing the demand for sod. This information was used to design, develop, and implement telephone surveys, the second part of the research. A total of 316 completed questionnaires were obtained from firms in 13 states, representing eight (8) distinct Standard Industrial Classifications (SIC). Data were analyzed by: 1) geographic subregion - west-coastal and west-interior, and; 2) type of business - contractors and developers, landscape service firms, retail garden centers, and sports turf facilities.

Just as primary market outlets differed between the central and eastern regions of the country, the western region also varied considerably. The retail sector dominated the western region with 68 percent market share, followed distantly by landscape services (14 percent), contractors and developers (12 percent) and sports turf facilities (6 percent). This contrasts sharply with the central and eastern regions, which had a less skewed market share distribution. Considerable differences in the quantities of sod purchased were also apparent between the westcoastal (W-C) and west-interior (W-I) subregions. For instance, very little ( 0.3 percent) sod was bought by contractors in the W-I, but considerably more (11 percent) was purchased by their counterparts in W-C. Similarly, home improvement chains such as Home Depot and Lowe's were important outlets in W-I (46 percent), but much less so in W-C (22 percent). Landscape service firms had a 12 percent market share in W-I, but only 2 percent in W-C. Finally, market shares for sports turf facilities were negligible in subregions.

Use of grass varieties varied considerably between the two subregions, with bluegrass comprising over half (58 percent) of total purchases in W-I, whereas the bluegrass-fescue mix dominated (35 percent) in W-C. Ryegrass was important (21 percent) in the coastal subregion, but almost non-existent ( 2 percent) in the interior. Bermudagrass was slightly more important (18 percent) in $\mathrm{W}-\mathrm{I}$ than it was $\mathrm{W}-\mathrm{C}$ (12 percent).

Comparing the use of sod versus seed, little difference surfaced by subregion, but noticeable disparities were observed by buyer category. More than any other group, contractors clearly preferred sod over seed, with over a 90 percent use rate. The retail sector and landscape services were roughly equal, with shares varying from roughly 50 percent in the interior to a high of 70 percent in the coastal areas. For the sports turf group, they preferred seed slightly more than sod with a 45 percent market share. 
Compared to the studies conducted in the Eastern and Central U.S., past activity and future business outlooks were less positive. Respondents were asked how their business volume had changed from the previous year (2000). Just under two-thirds (63 percent) claimed that business activity had grown, but this was down from 81 percent for the central U.S. a year earlier. Nearly 20 percent claimed there had been no change in business activity, and another 20 percent indicated it had actually declined. With regard to the future outlook, roughly forty percent felt it would improve in the coming year, another 22 percent felt there would be no change, and another 40 percent believed business activity would actually decline.

Results demonstrate that although there are common threads to both western geographic regions, pronounced differences were also apparent. Disparities became more prominent as the data were analyzed into smaller market segments. Results strongly suggest that producers interested in maximizing their marketing strategies must pay special attention to the differing needs and expectations of the target markets they are pursuing.

Keywords: western region, market demand, product characteristics, product supply, sod.

Acknowledgment. This research was sponsored by the International Turfgrass Producers Foundation, Rolling Meadows, IL. 


\section{Table of Contents}

Introduction $\ldots \ldots \ldots \ldots \ldots \ldots \ldots \ldots \ldots \ldots \ldots \ldots \ldots \ldots \ldots \ldots \ldots \ldots \ldots$

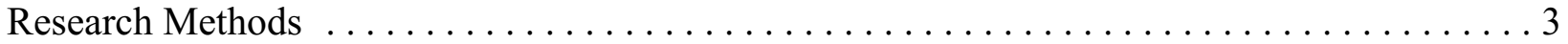

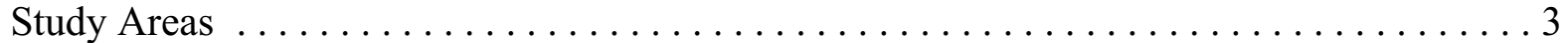

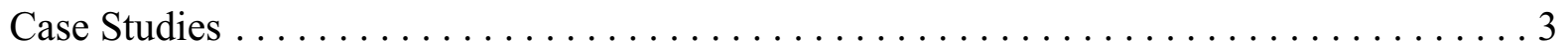

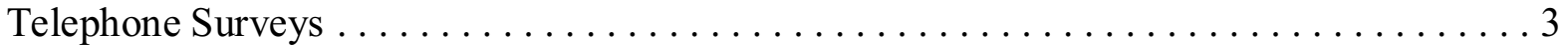

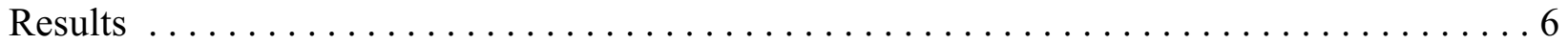

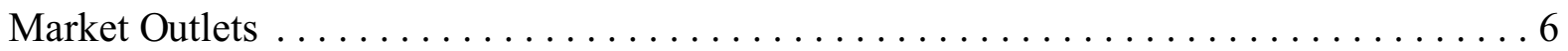

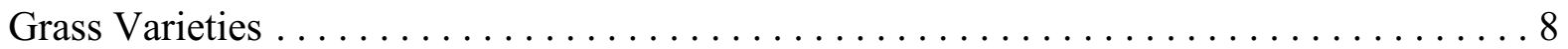

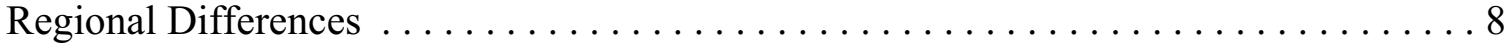

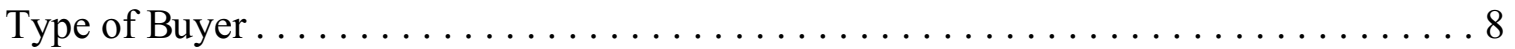

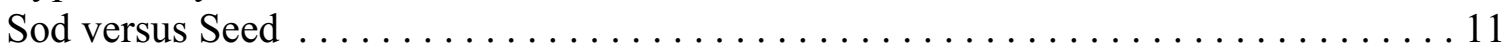

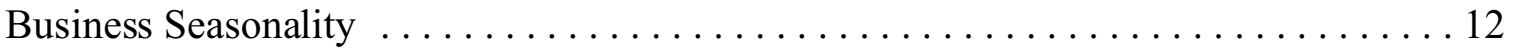

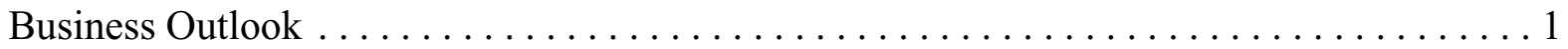

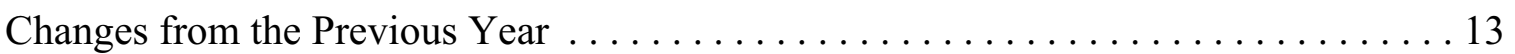

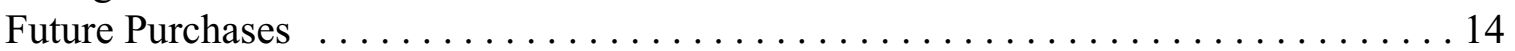

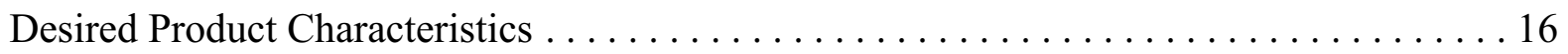

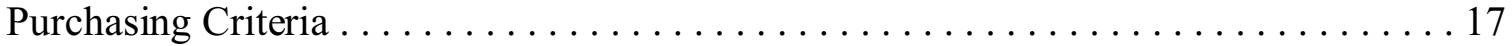

Features Liked Most about Sod . . . . . . . . . . . . . . . . . . . . . . 17

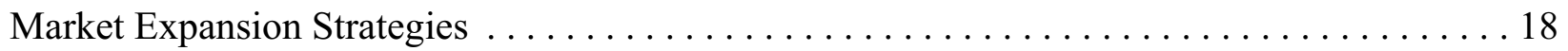

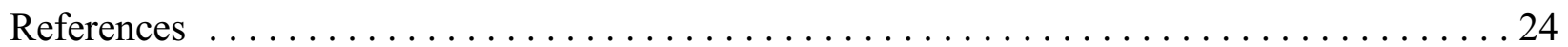




\section{List of Tables}

Table 1. Number of respondents interviewed, by turfgrass buyer category, in two regions of the

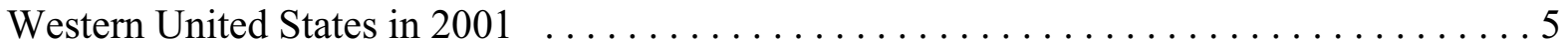

Table 2. Number of respondents interviewed by type of business and annual sales volume, 2001

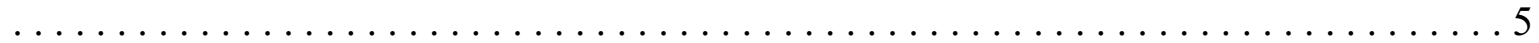

Table 3. Total square feet of sod purchased, by type of turfgrass buyer, in two regions of the

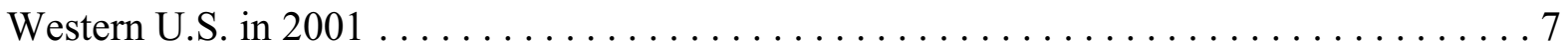

Table 4. Value, quantity and average price of major turfgrass types purchased, by type of buyer

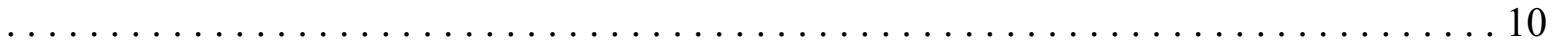

Table 5. Changes in business volume that occurred during 2000 for turfgrass related businesses

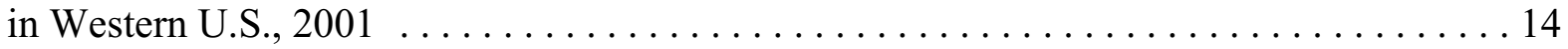

Table 6. Expectations regarding sod purchases next year (2002), by type of business, for firms in

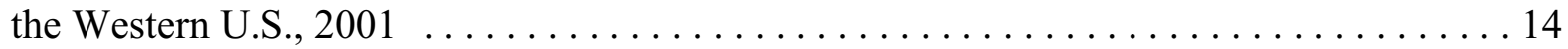

Table 7. Expectations regarding sod purchases in the next 3-5 years, by type of business, for

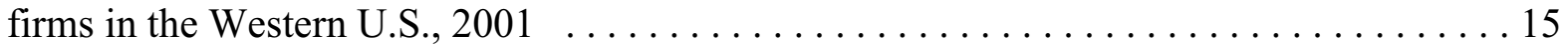

Table 8. Difficulty in obtaining sod when and where it is needed by firms in the Western U.S.,

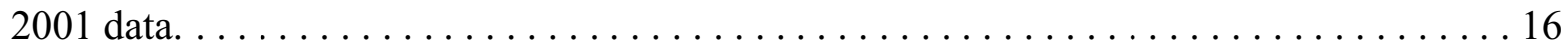

Table 9. Weighted averages of respondents' rankings regarding the importance of various purchasing criteria and features liked most about sod, U.S. Western data, 2001 . . . . . 17

\section{List of Figures}

Figure 1. Illustration of marketing system for turfgrass-sod and traditional product flow . . . . . 2

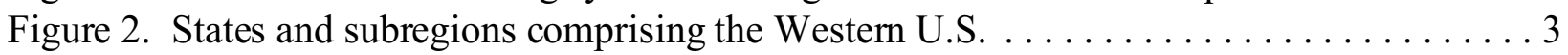
Figure 3. Average years in business as specified by the type of respondent interviewed, 2001 . 6 Figure 4. Comparison of market shares of turfgrass from various types of buyers in the Eastern,

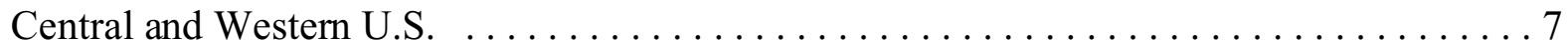
Figure 5. Comparison of market shares of turfgrass from buyer groups in the Western U.S., 2001

Figure 6. Major types of grasses purchased by respondents in the Western U.S., 2001 . . . . . 9 Figure 7. Percentage of total product volume purchased as sod compared to seed, from buyers in

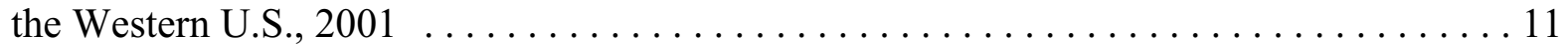
Figure 8. Seasonality of business volume for turfgrass related firms in the Western U.S., 2001 


\title{
Market Expansion Strategies for Turfgrass Producers in the Western United States
}

\author{
John J. Haydu, Alan W. Hodges and Loretta N. Satterthwaite ${ }^{1}$
}

\section{Introduction}

This report represents the third and final component of a market research study funded by the International Turfgrass Producers Foundation (ITPF). The previous two phases of this study were conducted in the Eastern and Central United States. The purpose of the study was to identify meaningful strategies to increase the demand for sod. When the first report was published (Haydu and Hodges, 2000), the U.S. economy was strong. In spite of minor grower concerns, overall market demand for sod in the eastern U.S. was healthy. At the same time, it was clear that many customers served by producers were frustrated by these favorable grower conditions. From a customer's perspective, not being able to find sod when it was needed, where it was needed, and how it was needed were the most fundamental marketing problems. Part of the problem lies with the inherent nature of sod (i.e., bulky and highly perishable) and that it is handled differently than most agricultural commodities. Rather than utilizing traditional marketing channels, most sod is purchased at the wholesale level directly from the farm. Because producers expect customers to come to them, many market opportunities were overlooked in this region. ${ }^{2}$

A year after the first report was issued, results of the second phase, covering the Central U.S., were made available (Haydu and Hodges, 2001). As expected, many of the same problems that surfaced in the eastern region were also present in the central region. However, there were also some important differences. For instance, retailers in the eastern U.S. (1999 study) accounted for the largest share of sod purchases (44 percent), but comprised less than half that number (21 percent) in the central U.S. Conversely, the landscape service sector was the predominant outlet in the central U.S. with 41 percent market share but it only accounted for 28 percent of sales in the east. In addition, the sports turf markets and contractors also showed considerable differences. The point is, markets often differ depending on the circumstances that define them. For sod production, climate and economic conditions influence what is being produced, how it is produced, and where it is sold. In spite of differences, one can also expect similarities.

Once sod leaves the farm, it usually passes through one or more marketing channels and is eventually used for new residential or commercial developments, for re-landscaping existing developments, for sports turf facilities such as athletic fields and golf courses, or for commercial applications that include businesses, public and private schools, and roadside uses (Haydu et al., 2002). A conceptual illustration of product flows within the sod production-marketing system and its major players is shown in Figure 1. For simplicity, the sod market is divided into two

\footnotetext{
${ }^{1}$ John J. Haydu is a Professor and Alan W. Hodges is Assistant-In, both with the Food and Resource Economics Department, Institute of Food and Agricultural Sciences, University of Florida. Loretta N. Satterthwaite is a Senior Statistician at the University of Florida's Institute of Food \& Agricultural Sciences' Mid-Florida Research and Education Center, Apopka.
}

${ }^{2}$ For detailed coverage of these and other issues in the eastern region, see Haydu and Hodges, 2000. 
primary sectors - new developments, comprising roughly 75 percent and existing homes and commercial businesses covering the remaining 25 percent. For new developments, it is estimated that roughly a third of total volume is sold through landscape contractors, and the other twothirds by sod installers. In essence, these segments represent the array of possibilities that producers must consider in their marketing strategy.

The final customer for sod can be the homeowner, a golf course, or an elementary school. Each of them has different circumstances and, hence, different expectations. Thus, the producer needs to take these different needs into account. Although the customer generally decides the type of sod to purchase, the installer also plays an important role. Both the landscape contractor and sod installer often make the decision from whom to buy and may even recommend to the homeowner the type of sod to plant. Hence, although both the final consumer and the middleman are important, the latter is critical from the producers' perspective, and so both sets of customers should be considered.

The purpose of this study is to address these marketing issues and to identify practical strategies for expanding sod markets. The report consists of three parts. Part one presents a brief overview of the survey methods employed. Part two introduces important findings of the research in the western region and, where applicable, compares results with the other regions. Part three offers specific marketing recommendations for western sod producers.

Figure 1. Illustration of marketing system for turfgrass-sod and traditional product flow.

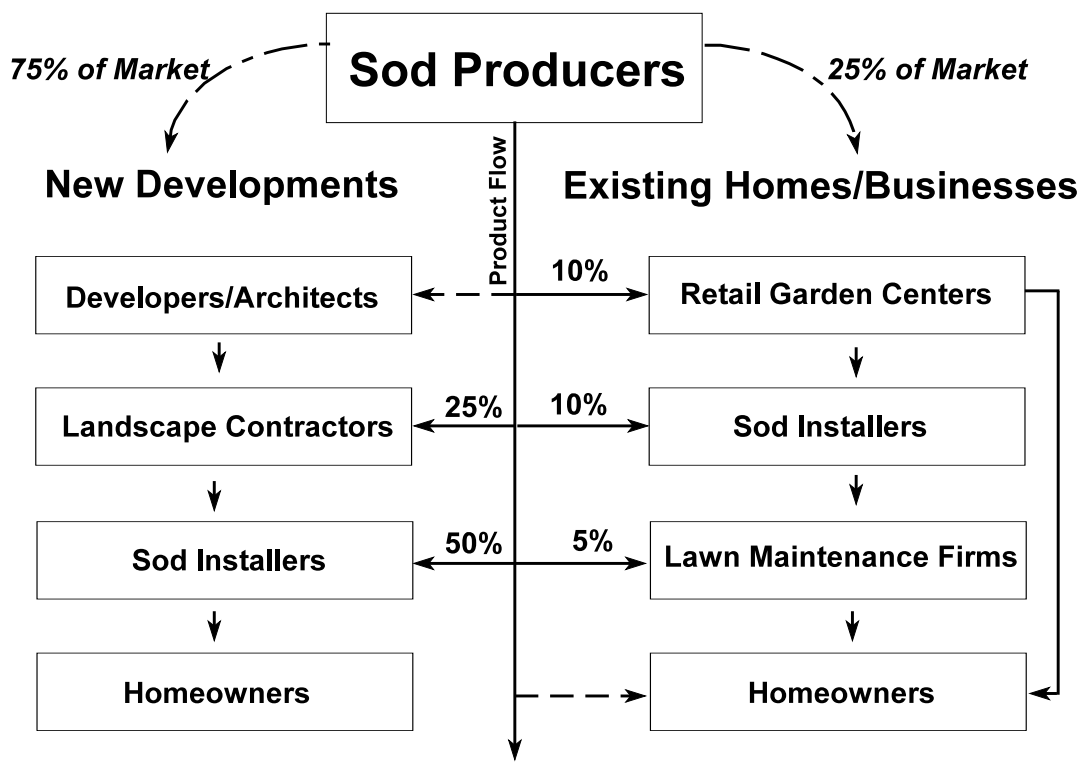




\section{Research Methods}

Study Areas. The research focused on the western portion of the United States. Due to the geographic diversity this large area represents, and in order to make project results more applicable to producers in different parts of the study area, it was further delineated into two subregions as shown in Figure 2.

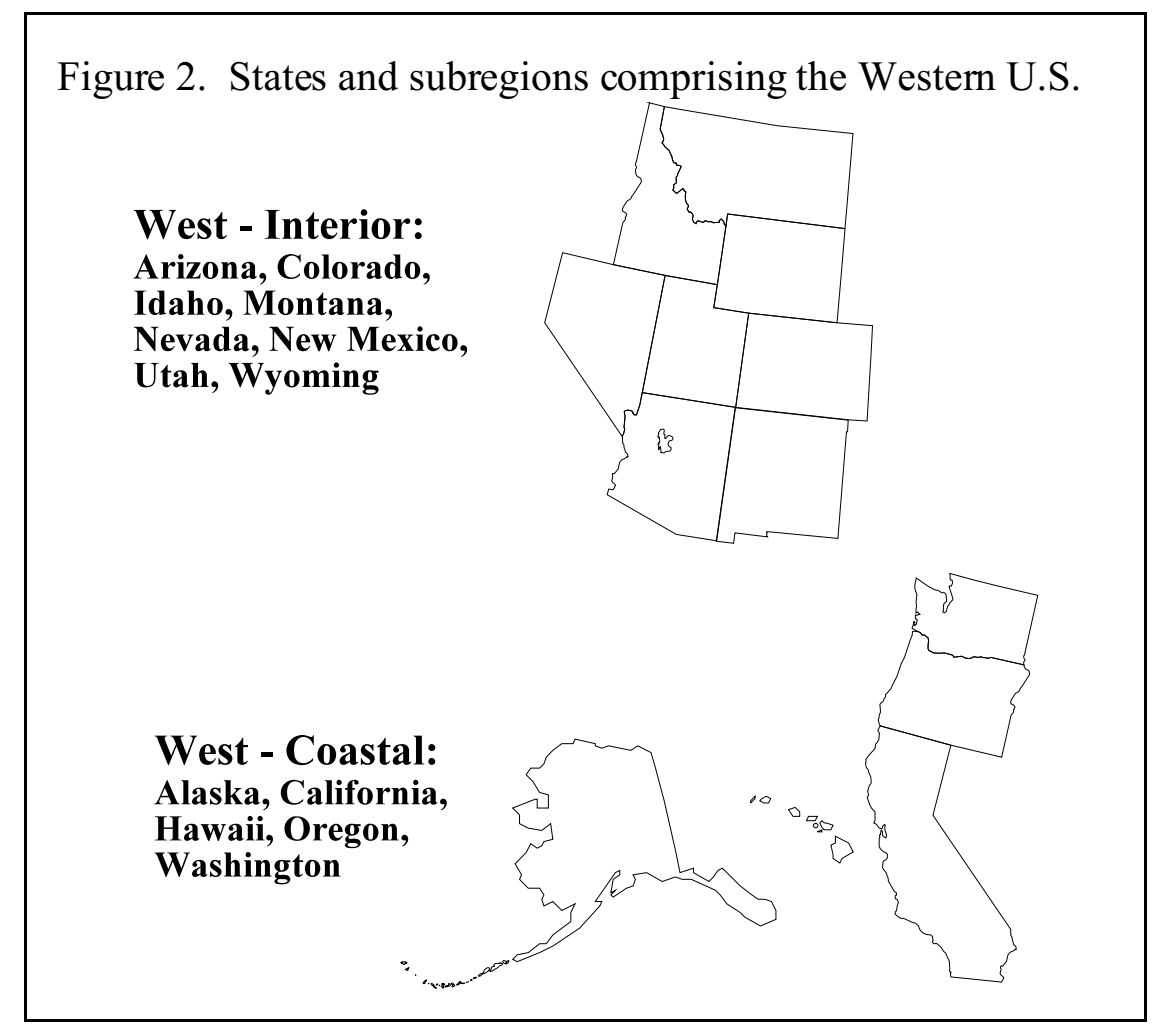

Case Studies. Case studies were conducted through personal interviews to identify important factors affecting sod demand in each major geographic area. The types of companies interviewed included: 1) several sod producers, 2) a vertically integrated sod producerdistributor-landscaper and irrigation contractor, 3) a medium-sized landscape nursery, 4) several landscape design and architectural firms, 5) landscape contractors, and 6) a large hydro-seeding company. Preliminary questionnaires were developed for the interviews, which were conducted at the business site and took between 1 and $1 \frac{1}{2}$ hours to complete. The information was compiled and organized for the second phase of the research process, the telephone surveys.

Telephone Surveys. Whereas case studies provide the basic information to determine strategic opportunities, telephone surveys establish authenticity through a large random sample of representative firms. Phone surveys are useful because they allow a wide spectrum of people to be covered within a short time period. Although mail surveys can provide more detail, acquiring an adequate sample often takes several months, while telephone surveys can be completed in a fraction of this time. However, a limitation of phone interviews is that only a brief time is 
available to obtain the information. Therefore, questions must be concise and target a specific issue. Establishing which questions should or should not be included in the interview is an essential function of case studies.

Respondents fell into four main categories based on Standard Industrial Classification (SIC) codes developed by the U.S. Department of Commerce. These four sectors were: 1) General Contractors, 2) Landscape Services, 3) Retailers, and 4) Sports Turf Users, including the following SIC categories:

- General Contractors - General contractors and developers of single family housing construction (SIC 1521), commercial residential construction (SIC 1522) and nonresidential construction (SIC 1542).

- Landscape Services - Landscape architects comprising landscape counseling and planning (SIC 0781), lawn and garden services (SIC 0782), hydro-seeding contractors (SIC 078213), sodding services (SIC 078203), landscape contractors (SIC 078204) and lawn maintenance firms (SIC 078206).

- Retailers - Nurseries and garden centers (SIC 5261).

- Sports Turf-Sports turf and golf courses comprising public golf courses (SIC 7992) and membership sports and recreation clubs, including private golf clubs (SIC 799700). Athletic field maintenance (SIC 078216) and Stadiums, Arenas, and Athletic Fields (SIC 794104).

A random sample of firms were selected within these sectors. Lists of firms were purchased from Marketing Systems Group, an authorized vendor for data products from American Business Information, the original source for the lists. A total of 316 firms were interviewed from the 13 states. Data were analyzed based on geographic region and business category - general contractors, landscape services, retail garden centers and sports turf businesses (Table 1). As noted, each group actually represents a substantially broader range of business types, accounting for a total of seven (7) four-digit SIC codes. These businesses were selected because they represent both major and minor turfgrass markets and were the most likely to possess knowledge concerning market opportunities.

In addition to the type of business, annual sales volume (size) can influence sod purchases. Table 2 provides information on the number of firms interviewed within four class sizes based on annual business volume - small (less than $\$ 500$ thousand); medium ( $\$ 500$ thousand to $\$ 2.5$ million); large (\$2.5 million - \$10 million); and very large (over \$10 million). A total of 134 small, 86 medium, 27 large and 8 very large businesses were interviewed in this study.

Another variable considered was the duration the company had been in business. Owners or managers with extensive turfgrass experience were desired since this group should have considerable knowledge concerning challenges and opportunities for the sod production industry. Figure 3 shows the average years in business for the four types of companies. Landscape services averaged the least with 16 years, followed by general contractors with 19 years, retailers had 21 years experience and sports turf users had the most with 31 years. 
Table 1. Number of respondents interviewed, by turfgrass buyer category, in two regions of the Western United States in 2001.

\begin{tabular}{|c|c|c|c|c|c|c|}
\hline \multirow{2}{*}{ Type of Business } & \multicolumn{6}{|c|}{ Region } \\
\hline & \multicolumn{2}{|c|}{ West-Coastal $^{1}$} & \multicolumn{2}{|c|}{ West-Interior ${ }^{2}$} & Total & Percent \\
\hline General Contractors $^{3}$ & \multicolumn{2}{|l|}{8} & \multicolumn{2}{|c|}{13} & 21 & $7 \%$ \\
\hline Landscape Services ${ }^{4}$ & \multicolumn{2}{|l|}{68} & \multicolumn{2}{|c|}{42} & 110 & $35 \%$ \\
\hline Retailers $^{5}$ & \multicolumn{2}{|l|}{86} & \multicolumn{2}{|c|}{27} & 113 & $36 \%$ \\
\hline Sports Turf ${ }^{6}$ & \multicolumn{2}{|l|}{40} & \multicolumn{2}{|c|}{32} & 72 & $22 \%$ \\
\hline All Industries & \multicolumn{2}{|l|}{202} & \multicolumn{2}{|c|}{114} & 316 & $100 \%$ \\
\hline \multicolumn{7}{|c|}{$\begin{array}{l}1 \text { West-Coastal region includes Alaska, California, Hawaii, Oregon and Washington. } \\
2 \text { West-Interior region includes Arizona, Colorado, Idaho, Montana, Nevada, New Mexico, Utah and Wyoming. } \\
3 \text { Category includes general contractors and developers of single family housing construction (SIC 1521), } \\
\text { commercial residential construction (SIC 1522) and non-residential construction (SIC1542). } \\
4 \text { Category includes landscape architects and contractors comprising landscape counseling and planning (SIC 0781) } \\
\text { and lawn and garden services (SIC 0782). } \\
6 \text { Nurseries and garden centers (SIC 5261). } \\
\text { Sports turf and golf courses comprising public golf courses (SIC 7992) and membership sports and recreation } \\
\text { clubs, including private golf clubs (SIC 799700). }\end{array}$} \\
\hline Annual Sales Volume & $\begin{array}{c}\text { General } \\
\text { Contractor }\end{array}$ & & $\begin{array}{l}\text { dscape } \\
\text { vices }\end{array}$ & Retailers & Sports Turf & $\begin{array}{c}\text { Total } \\
\text { Number }\end{array}$ \\
\hline Less than $\$ 500,000$ & 4 & & 56 & 57 & 17 & 134 \\
\hline$\$ 500,000-\$ 2.5$ million & 6 & & 32 & 22 & 26 & 86 \\
\hline$\$ 2.5$ million $-\$ 10$ million & 3 & & 9 & 5 & 10 & 27 \\
\hline Over $\$ 10$ million & 4 & & 1 & 2 & 1 & 8 \\
\hline Not Available & 4 & & 12 & 27 & 18 & 61 \\
\hline Total Number & 21 & & 10 & 113 & 72 & 316 \\
\hline
\end{tabular}


Figure 3. Average years in business as specified by the type of respondent interviewed, 2001

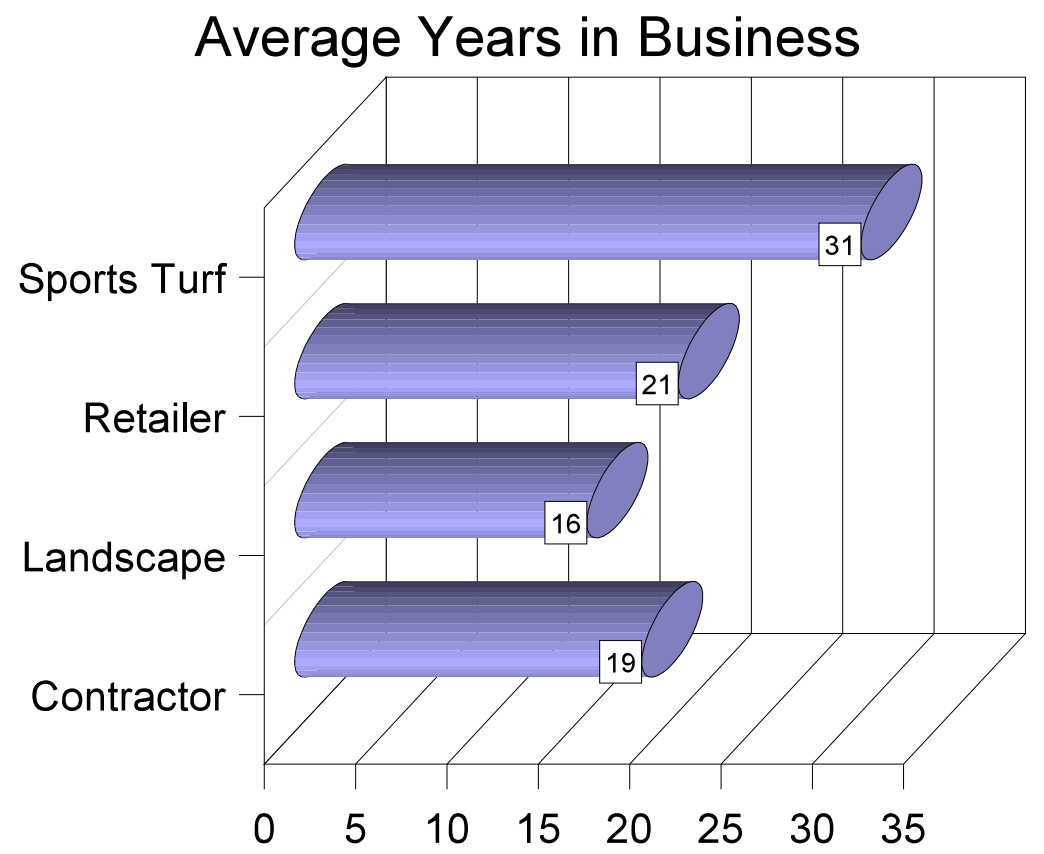

\section{Results}

\section{Market Outlets}

As noted earlier, turfgrass sod customers have been grouped into four broad categories, although each also consists of several smaller categories based on SIC codes used by the Department of Commerce. For the Western U.S., by far the most important sod market was retailers with 68 percent share (Table 3), landscape services followed a distant second with 14 percent market share, general contractors with 12 percent, and finally sports turf businesses comprising 6 percent market share. Roughly 75 percent of this sod was purchased in the westinterior region and, within this sector, retailers were the largest buyer group and sports turf businesses the smallest. Although the west-coastal region consumed considerably less sod, like their west-interior counterpart, retailers were also the predominant consumer of sod.

U.S. Inter-regional Assessment. When buyer groups are compared on a larger regional scale, substantial variations in purchasing patterns are evident (Figure 4). For example, retailers dominated market shares in the western (68 percent) and eastern U.S. (44 percent), but were of relatively minor ( 21 percent) importance in the central U.S. This large discrepancy in retail dominance may be partly explained by the fact that use of this outlet is a relatively recent phenomenon. In other words, with time this market outlet could expand in the central region also. 
Table 3. Total square feet of sod purchased, by type of turfgrass buyer, in two regions of the Western U.S. in 2001.

\begin{tabular}{|c|c|c|c|c|}
\hline \multicolumn{4}{|c|}{ Region } & \\
\hline \multicolumn{2}{|c|}{ West-Coastal } & \multicolumn{2}{|c|}{ West-Interior } & \\
\hline Total & Average & Total & Average & Share \\
\hline
\end{tabular}

\begin{tabular}{lrrrrr} 
Type of Business & \multicolumn{3}{c}{-----------------S Square Feet ------------------ } \\
\hline General Contractors & 263,500 & 37,643 & $10,673,000$ & 889,417 & $12 \%$ \\
Landscape Services & $2,323,660$ & 35,749 & $11,133,820$ & 278,346 & $14 \%$ \\
Retailers & $20,569,420$ & 298,108 & $43,256,320$ & $1,880,710$ & $68 \%$ \\
Sports Turf & $1,720,284$ & 46,494 & $3,958,960$ & 136,516 & $6 \%$ \\
All Industries & $24,876,864$ & 139,758 & $69,022,100$ & 663,674 & $100 \%$ \\
\hline
\end{tabular}

Figure 4. Comparison of market shares of turfgrass from various types of buyers in the Eastern, Central and Western U.S.

\section{Relative Market Shares \\ Square Feet Purchased}

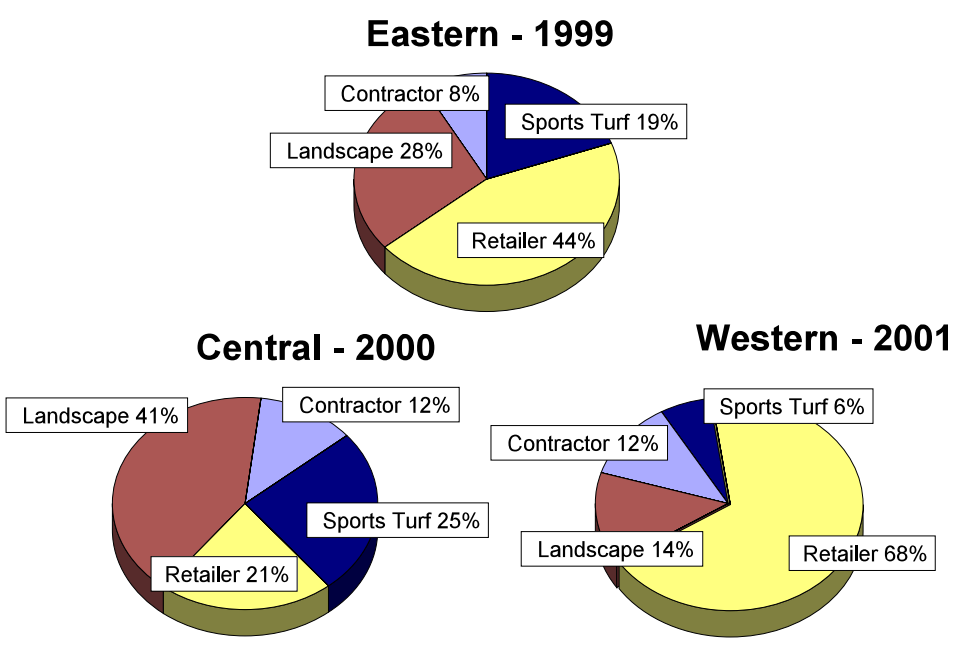


Landscape services were the prevailing sector in the central region (41 percent), less so in the eastern ( 28 percent), and of minor consequence in the western section (14 percent). Sports turf businesses were more dominant in the central ( 25 percent) and eastern (19 percent) U.S., and of minor account ( 6 percent) in western regions. Finally, the contractor-developer group was a relatively minor player in all three regions, with 12 percent market share in central and western U.S., and only 8 percent in the eastern region.

Western Intra-regional Assessment. Reducing the geographic spectrum from regions to subregions provides a different yet equally meaningful perspective. Market share varied markedly across all buyer categories (Figure 5). The retail sector, dominated by home improvement chains such as Home Depot and Lowe's, were important distribution outlets in the interior sub-region with 46 percent share, compared to less than half that amount (22 percent) in the coastal subregion. Similarly, landscape services accounted for 12 percent market share in the west-interior, but only 2.5 percent along the coast. On the other hand, contractors were fairly significant buyers in the coastal region (11 percent) but were barely noticeable in the interior ( 0.3 percent). Finally, sports turf buyers, representing the smallest buyer category in the western U.S., bought 4 percent and 2 percent of the total purchases in the interior and coastal regions, respectively.

These results have important implications for sod producers. First, although contractors will likely remain a traditional market channel for sod in the west-coastal, clearly the retail sector has made important inroads. For instance, although retailers in the interior were used twice as much as the coastal area, the 22 percent market share of this coastal group is still more than double all other groups. Second, the type of product used by chains has begun to shift away from plugs to more sod. Chain store managers and producers indicated that sales to homeowners and small landscape contractors had grown appreciably in recent years for use in minor landscape renovations.

\section{Grass Varieties}

Regional Differences. As one would expect, grass variety preferences among respondents were highly influenced by geographic location (Figure 6). In the west coastal region, three grass varieties dominated the market - bluegrass/fescue mix (35 percent), followed by fescue ( 21 percent), and ryegrass (20 percent). The more minor varieties were bermudagrass (12 percent), St. Augustinegrass (4 percent) and bluegrass (4). In contrast, states within the west-interior overwhelmingly favored bluegrass, comprising nearly 60 percent of the total. Bermudagrass and fescue shared another one-third of the market, with the remaining 7 percent comprised of bluegrass/fescue and ryegrass. In summary, whereas the bluegrass/fescue mix and ryegrass dominated in the coastal area, they were very minor in the interior. Similarly, the number one variety in the interior has a negligible impact in the coastal region.

Type of Buyer. Purchasing characteristics varied according to buyer type and grass variety (Table 4). For bluegrass, retailers purchased 88 percent of total value and 89 percent of the total quantity. Sports turf buyers paid a higher per unit price $(\$ 0.19)$ for their sod, but bought the lowest quantity and, even with the higher price, only purchased 2 percent of the market value of bluegrass. Bluegrass was the only grass of the top three in the western U.S. - bluegrass, fescue and bermudagrass - that all types of buyers bought. 
Figure 5. Comparison of market shares of turfgrass from buyer groups in the Western U.S., 2001.

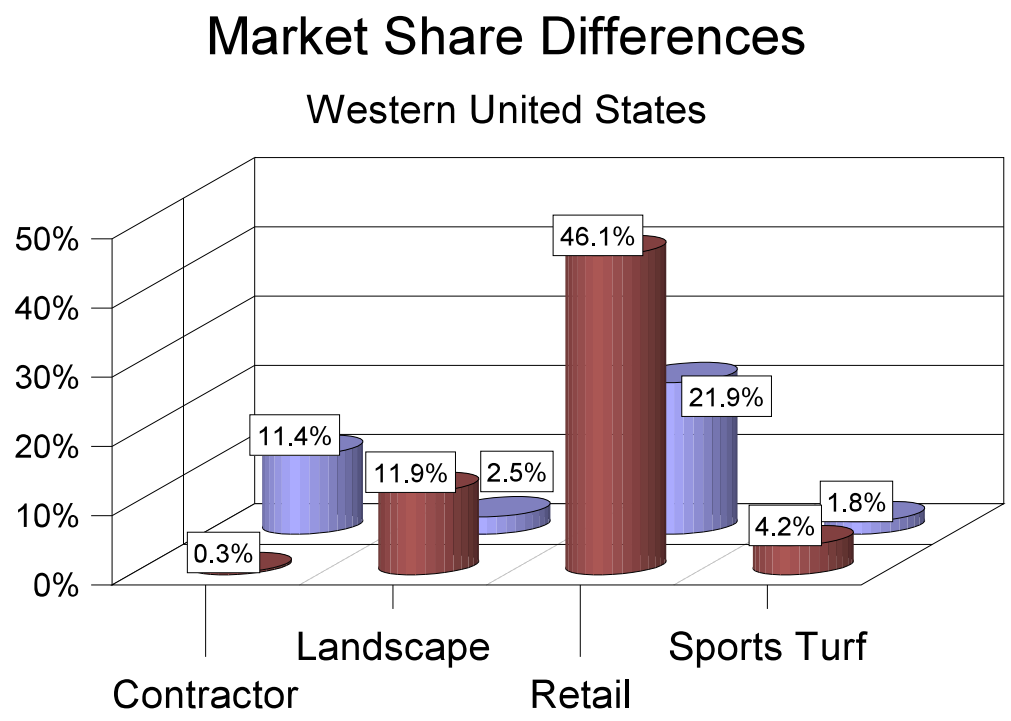

$\square$ West-Coastal $\square$ West-Interior

Figure 6. Major types of grasses purchased by respondents in the Western U.S., 2001.

\section{Major Grass Varieties Used}

Western U.S.

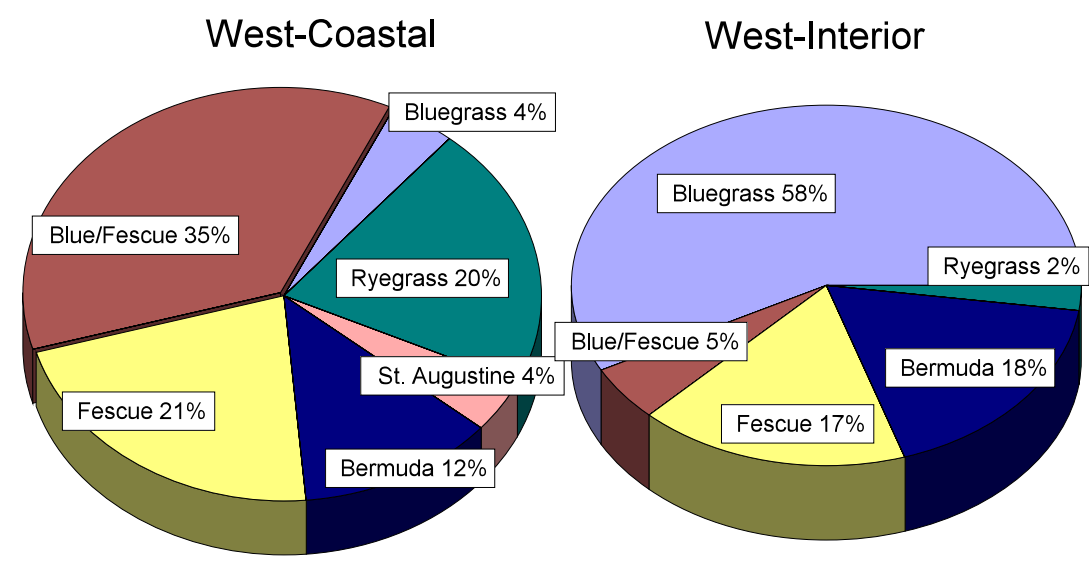


Table 4. Value, quantity and average price of major turfgrass types purchased, by type of buyer (for respondents reporting both value and quantity purchased).

\begin{tabular}{lrrrrr}
\hline Type of Turfgrass \& Buyer & \multicolumn{1}{c}{$\begin{array}{c}\text { Value } \\
(\$ 000)\end{array}$} & $\begin{array}{r}\text { Percent } \\
\text { Share }\end{array}$ & $\begin{array}{r}\text { Quantity } \\
\left(000 \mathrm{ft}^{2}\right)\end{array}$ & $\begin{array}{r}\text { Percent } \\
\text { Share }\end{array}$ & $\begin{array}{r}\text { Price } \\
\left(\$ / \mathrm{ft}^{2}\right)\end{array}$ \\
\hline Bluegrass & $\$ 2,961.2$ & $100 \%$ & $26,323.6$ & $100 \%$ & $\$ 0.11$ \\
\hline General Contractors & $\$ 96.5$ & $3 \%$ & 587.0 & $2 \%$ & $\$ 0.16$ \\
Landscape Services & $\$ 202.9$ & $7 \%$ & $1,964.0$ & $7 \%$ & $\$ 0.10$ \\
Retailers & $\$ 2,595.1$ & $88 \%$ & $23,424.6$ & $89 \%$ & $\$ 0.11$ \\
Sports Turf & $\$ 66.5$ & $2 \%$ & 348.0 & $1 \%$ & $\$ 0.19$ \\
& & & & & \\
Fescue & $\$ 14,416.1$ & $100 \%$ & $14,416.8$ & $100 \%$ & $\$ 1.00$ \\
\hline General Contractors & $(<1)$ & $(<1)$ & $(<1)$ & $(<1)$ & $(-)$ \\
Landscape Services & $\$ 10,635.5$ & $74 \%$ & $5,966.1$ & $41 \%$ & $\$ 1.78$ \\
Retailers & $\$ 3,780.0$ & $26 \%$ & $8,450.2$ & $59 \%$ & $\$ 0.45$ \\
Sports Turf & $(<1)$ & $(<1)$ & $(<1)$ & $(<1)$ & $(-)$ \\
& & & & & \\
Bermudagrass & $\$ 6,978.6$ & $100 \%$ & $13,351.7$ & $100 \%$ & $\$ 0.52$ \\
\hline \hline General Contractors & $(<1)$ & $(<1)$ & $(<1)$ & $(<1)$ & $(-)$ \\
Landscape Services & $\$ 714.7$ & $10 \%$ & 540.8 & $4 \%$ & $\$ 1.32$ \\
Retailers & $\$ 6,059.4$ & $87 \%$ & $12,225.9$ & $92 \%$ & $\$ 0.50$ \\
Sports Turf & $\$ 204.1$ & $3 \%$ & 579.9 & $4 \%$ & $\$ 0.35$ \\
\hline
\end{tabular}

For the fescue, landscape services and retailers were the only significant purchasers in the western U.S. Landscape services purchased 41 percent by quantity, but because of the high price that they paid for sod ( $\$ 1.78$ per square foot), they were responsible for 74 percent of the value of this type of sod.

Retailers dominated the market for bermudagrass both in terms of quantity ( 92 percent) and value (87 percent), suggesting that bermudagrass is very important to them. Some landscape services must have utilized bermudagrass for specialized jobs that included a substantial service component to have such a high unit price ( $\$ 1.32$ per square foot). They purchased only 4 percent of this sod by quantity, but because of the high price, it translated into 10 percent by value. Interestingly, sports turf buyers who paid high prices for the bluegrass, paid the least for their bermudagrass. Similarly, contractors represented a negligible component within this category.

Conclusions regarding purchasing characteristics of major customer categories are found by combining results across grass varieties. Large variations exist within market groups, or even within a smaller market segment. For example, landscape services include landscape architects and contractors in addition to lawn maintenance businesses. A high-end design and contracting firm developing landscapes for prominent commercial establishments will have a different set of financial parameters than will a small contractor renovating landscapes for a middle-class 
neighborhood. To satisfy customers producers must identify relevant differences and offer a product and/or service that meets the expectations of the clients being served.

Sod versus Seed. A factor examined in this study was the proportion of land that was planted in sod as opposed to seed. From a marketing perspective, regions that utilize a greater proportion of seed could potentially offer a correspondingly larger market for sod. In terms of use patterns across business categories, contractors used sod instead of seed for nearly all their needs with coastal areas using slightly more sod than the interior (Figure 7). Both retailers and landscape services in the coastal regions used sod for nearly two-thirds of their purchases, while the same two categories in the interior used sod for about half of their purchases. Sports turf facilities sodded under one-half of their turf areas, regardless of location.

There are market opportunities for increasing sod sales by enticing current grass seed users to buy sod in the interior, where more seed is currently being used, and perhaps less abundant the nearer the coast one goes. Most notably, sports turf companies who used only 45 percent sod, should be looked at from a marketing standpoint. Are they using less sod because they are experiencing weather that does not lend itself to outdoor activities or should they be encouraged to use sod so that they do not have long periods of down time from their playing fields? Given also the fact that turf-wear is much more intensive, necessitating more frequent replacement, this group could very feasibly be an additional market for sod.

Figure 7. Percentage of total product volume purchased as sod compared to seed, from buyers in the Western U.S., 2001.

\section{Percent Product Volume in Sod versus Seed}

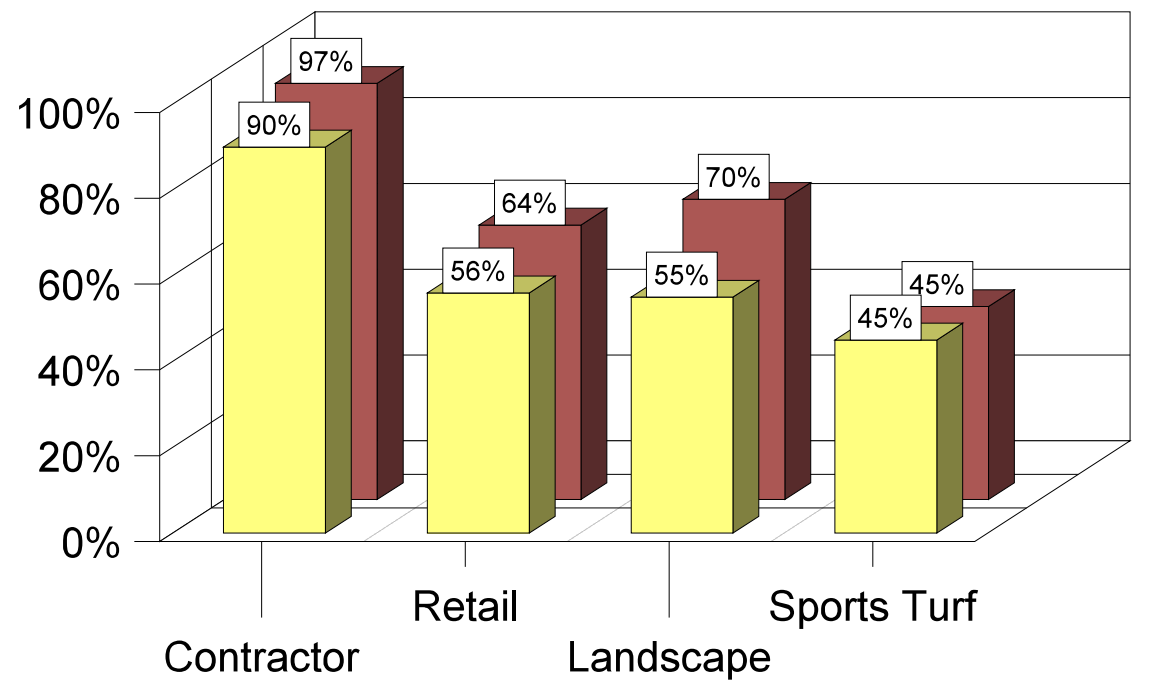

West-Coastal

West-Interior 
Business Seasonality. A related variable influencing the utilization of sod is seasonality of the business. Marketing strategies might target slow or fast periods, depending on the firm's objectives and where opportunities arise. For the firms interviewed, the peak periods were in the spring and summer, with winter being the slack period (Figure 8). There was almost no difference in seasonality between growers from the coast and the interior. For some sod producers, the interval with the most activity might indicate the greatest opportunities, since demand at this time would be highest. On the other hand, since most producers are busy at this time, it might also be the most competitive period so a possible strategy could be to target periods of low intensity and create market opportunities. For instance, slow winter months might be a good time to contact state and local governments who need lower quality grass for roadsides and drainage areas. In many southeastern states, sod is the preferred cover for all new or newly renovated roadside projects. These projects require enormous volumes of lower-quality sod to prevent erosion and beautify the surrounding landscapes. Since turf quality is already compromised during this time of year, offering a lower price to move excess production may be a viable strategy. From an operational and cash-flow standpoint, it makes sense to even out the peaks and troughs of business activity throughout the year.

\section{Seasonality of Business}

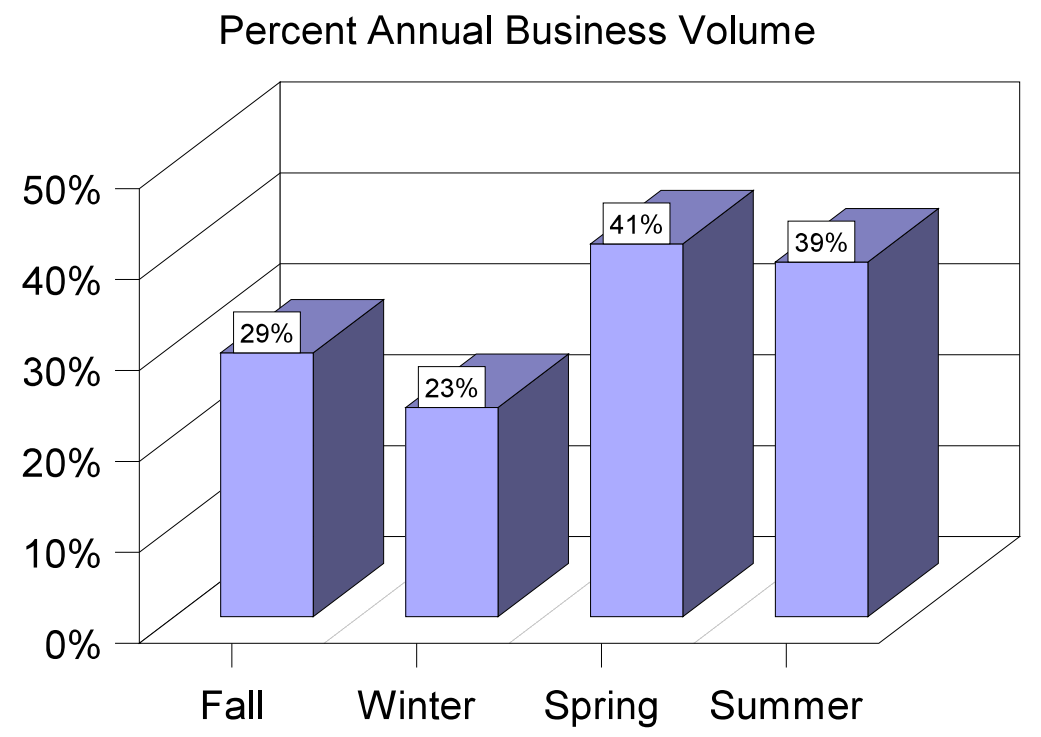

Figure 8. Seasonality of business volume for turfgrass related firms in the Western U.S., 2001. 


\section{Business Outlook}

Sod production, like most business activities, involves a certain degree of risk. Producers make daily decisions that often have impacts felt for many years into the future. Decisions like the types of grasses to plant, how much of each variety, capital investments that should be made, land improvements that will improve sod quality and enhance production efficiencies, and the "break-even" price necessary to sustain solvency and profitability are just some of the many troubling issues that managers and owners must address on a continual basis. Since the demand for sod is so closely tied to housing starts, which in turn is affected by interest rates and the general health of the economy, knowledge of these issues is essential. How well informed the owner/manager is regarding issues surrounding a particular problem affects the type and quality of the final decision that is made. For example, deciding to expand the business under conditions of a slowing economy could be risky, depending on the circumstances of the producer and the particular market being served. Obtaining the opinions of important sod clients who are "downstream" in the production-distribution channel provides unique and valuable perspectives for sod producers.

To illustrate a point - in the past five years, Florida sod production has mushroomed due to increased demand, largely from housing construction and numerous road projects. This increased supply was the result of new entrants coming into the industry, and some existing sod producers expanding production. Eventually supply caught up with and eventually exceeded demand (Haydu et al., 2002). Today the industry is facing strong downward pressures on prices, a condition that has been dragging on for over a year. If some of the more aggressive producers had watched the market more closely, they would have realized that the level of growth that was occurring was not sustainable. Expanding output when demand is sharply slowing not only jeopardizes one's own firm, but causes difficulties throughout the entire industry.

Changes from the Previous Year. To assess current and future economic impacts to the sod market, respondents were asked how their business volume had changed from the previous year (2000). Nearly two-thirds of the firms (63 percent), regardless of type, stated that business activity had grown from the previous year (Table 5). Landscape services and retailers claimed that business had increased from the previous year. Only 5 percent of contractors and developers had seen an increase in business volume, which may reflect the present slowdown in the economy. Such expectations by this group could be discouraging for the sod industry, which relies on new residential and commercial construction. Construction contracts are usually multi-year and so, even with a downturn, it could take some time before the full impact is felt, giving producers an opportunity to respond accordingly. Eighteen percent of firms claimed that business had declined and 20 percent stated there was no change from the previous year. 
Table 5. Changes in business volume that occurred during 2000 for turfgrass related businesses in Western U.S., 2001.

\begin{tabular}{l|c|c|c|c|c|c}
\hline \multirow{2}{*}{ Type of Business } & \multicolumn{4}{c}{ Change in Business Volume from Previous Year } \\
\cline { 2 - 7 } & \multicolumn{2}{|c|}{ Increased } & \multicolumn{2}{c|}{ Decreased } & \multicolumn{2}{c}{ No Change } \\
\cline { 2 - 7 } & $\begin{array}{c}\text { Number of } \\
\text { Firms }\end{array}$ & $\begin{array}{c}\text { Percent of } \\
\text { Firms }\end{array}$ & $\begin{array}{c}\text { Number of } \\
\text { Firms }\end{array}$ & $\begin{array}{c}\text { Percent of } \\
\text { Firms }\end{array}$ & $\begin{array}{c}\text { Number of } \\
\text { Firms }\end{array}$ & $\begin{array}{c}\text { Percent of } \\
\text { Firms }\end{array}$ \\
\hline Contractors & 14 & $5 \%$ & 2 & $1 \%$ & 5 & $2 \%$ \\
Landscape & 76 & $25 \%$ & 13 & $4 \%$ & 20 & $6 \%$ \\
Retailers & 68 & $22 \%$ & 23 & $7 \%$ & 18 & $6 \%$ \\
Sports Turf & 36 & $12 \%$ & 17 & $5 \%$ & 18 & $6 \%$ \\
Total & 194 & $63 \%$ & 55 & $18 \%$ & 61 & $20 \%$ \\
\hline
\end{tabular}

Table 6. Expectations regarding sod purchases next year (2002), by type of business, for firms in the Western U.S., 2001.

\begin{tabular}{l|c|c|c|c|c|c}
\hline \multirow{2}{*}{ Type of Business } & \multicolumn{4}{c}{ Expected Change in Business Volume for Next Year } \\
\cline { 2 - 7 } & \multicolumn{2}{c|}{ Increase } & \multicolumn{2}{c|}{ Decrease } & \multicolumn{2}{c}{ No Change } \\
\cline { 2 - 7 } & $\begin{array}{c}\text { Number of } \\
\text { Firms }\end{array}$ & $\begin{array}{c}\text { Percent of } \\
\text { Firms }\end{array}$ & $\begin{array}{c}\text { Number of } \\
\text { Firms }\end{array}$ & $\begin{array}{c}\text { Percent of } \\
\text { Firms }\end{array}$ & $\begin{array}{c}\text { Number of } \\
\text { Firms }\end{array}$ & $\begin{array}{c}\text { Percent of } \\
\text { Firms }\end{array}$ \\
\hline Contractors & 6 & $2 \%$ & 9 & $3 \%$ & 6 & $2 \%$ \\
Landscape & 46 & $15 \%$ & 41 & $14 \%$ & 15 & $5 \%$ \\
Retailers & 51 & $17 \%$ & 39 & $13 \%$ & 15 & $5 \%$ \\
Sports Turf & 15 & $5 \%$ & 27 & $9 \%$ & 29 & $10 \%$ \\
Total & 118 & $39 \%$ & 116 & $39 \%$ & 65 & $22 \%$ \\
\hline
\end{tabular}

Future Purchases. Respondents were next asked about their expectations regarding sod purchases for the coming year (Table 6). In this case, fewer firms (39 percent) expressed confidence that business would continue to grow. In fact, compared to the previous year's growth, about 50 percent fewer firms had confidence that their business would improve. An equal percent expected business activity to decrease. A smaller proportion ( 22 percent) of businesses surveyed expected no change in business activity for the coming year (2001). Given that business volume was strong in 2000, this may be interpreted as an expression of business confidence from this group. As in the other two regions of the U.S., the group expecting the largest decline in business activity was sports turf users. Some golf course managers observed that their industry tends to be "project driven". During a period of project activity, managers may embrace a more optimistic outlook since expansion is often associated with economic health. Conversely, during a project hiatus, apprehensions may surface, including uncertainty about the economy and the financial risks a downturn portends. Sports turf facilities provide leisure activities that rely almost exclusively on discretionary income. During economic slowdowns, such expenditures are often the first to be cut by consumers. 
Respondents were asked to give a longer projection regarding their expectations for sod purchases. In general the business mood was not very optimistic. Only 12 percent of firms had sufficient confidence in the economy that they believed would warrant increased sod purchases in the next three-to-five years (Table 7). This compares to 37 percent that were confident in the Central U.S. survey, which pre-dated September $11^{\text {th }}$. More than half (51 percent) believed sod purchases would fall, and another 37 percent indicated no change. Breaking this down by business activity, the two categories that were the least optimistic were the contractors $(0.3$ percent) and sports turf businesses (3 percent). The landscape service sector and retailers were slightly more optimistic with 4 and 5 percent respectively. For declining purchases, landscape services and retailers were roughly equal, each representing about one-fifth of their respective categories. Fewer sports turf businesses were in this category, with only 11 percent of them expecting a decrease, while 4 percent of contractors felt that purchases would decline in the next 3-5 years. The same scenario was repeated for those indicating no expected change.

Finally, respondents were asked whether sod was difficult to obtain when and where it was needed. If a respondent claimed it was difficult to get, they were asked to rank the difficulty on a scale of $1-5$, with 5 being the most difficult (Table 8). Most respondents (81 percent) did not believe there were problems obtaining sod. Just over 6 percent of businesses felt it was difficult to obtain and another 12 percent indicated it was difficult sometimes. Of those that felt it was difficult, landscape services appeared to have the most serious problem with an average ranking of 4.2, followed by contractors with a 4. Retailers gave a difficulty factor of 3.5 and the sports turf category specified a value of 3 . Across all categories, the average ranking was 3.8. These results can be interpreted in two different ways. The good news is that four-fifths of all respondents in the Western U.S. did not have a problem acquiring sod. The bad news is that one-fifth of the firms interviewed did have a problem obtaining sod at least some of the time. Equally revealing, the gravity of the problem was serious in that the difficulty factor was valued at 3.8 on a scale of one-to-five. Simply stated, a significant portion of the sod market is not being adequately served. Of course the silver lining on this finding is that this group represents a viable market opportunity for those willing and able to capture it.

Table 7. Expectations regarding sod purchases in the next 3-5 years, by type of business, for firms in the Western U.S., 2001.

\begin{tabular}{|c|c|c|c|c|c|c|c|c|}
\hline \multirow[t]{3}{*}{ Type of Business } & \multicolumn{8}{|c|}{ Expectations for Sod Use in Next 3-5 Years } \\
\hline & \multicolumn{2}{|c|}{ Increase } & \multicolumn{2}{|c|}{ Decrease } & \multicolumn{2}{|c|}{ Same } & \multicolumn{2}{|c|}{ Total } \\
\hline & Number & Percent & Number & Percent & Number & Percent & Number & Percent \\
\hline Contractors & 1 & $0 \%$ & 12 & $4 \%$ & 8 & $3 \%$ & 21 & $7 \%$ \\
\hline Landscape & 13 & $4 \%$ & 58 & $19 \%$ & 38 & $12 \%$ & 109 & $35 \%$ \\
\hline Retailers & 15 & $5 \%$ & 56 & $18 \%$ & 39 & $13 \%$ & 110 & $35 \%$ \\
\hline Sports Turf & 9 & $3 \%$ & 34 & $11 \%$ & 29 & $9 \%$ & 72 & $23 \%$ \\
\hline Total & 38 & $12 \%$ & 160 & $51 \%$ & 114 & $37 \%$ & 312 & $100 \%$ \\
\hline
\end{tabular}


Table 8. Difficulty in obtaining sod when and where it is needed by firms in the Western U.S., 2001 data. (Difficulty on a scale of 1-5, with "5" being the most difficult.)

\begin{tabular}{|c|c|c|c|c|c|c|c|c|}
\hline \multirow{2}{*}{\multicolumn{2}{|c|}{ Sector }} & \multicolumn{2}{|c|}{$\begin{array}{l}\text { Yes, difficult to } \\
\text { obtain sod }\end{array}$} & \multirow{2}{*}{$\begin{array}{c}\begin{array}{c}\text { How } \\
\text { difficult? }\end{array} \\
1-5 \\
\end{array}$} & \multicolumn{2}{|c|}{$\begin{array}{l}\text { Sometimes difficult } \\
\text { to obtain sod }\end{array}$} & \multicolumn{2}{|c|}{$\begin{array}{l}\text { Not difficult to } \\
\text { find sod }\end{array}$} \\
\hline & & Number & Percent & & Number & Percent & Number & Percent \\
\hline Contractors & & 1 & $0.3 \%$ & 4.0 & 1 & $0.3 \%$ & 19 & $6.1 \%$ \\
\hline Landscape & & 9 & $2.9 \%$ & 4.2 & 18 & $5.8 \%$ & 83 & $26.7 \%$ \\
\hline Retailers & & 6 & $1.9 \%$ & 3.5 & 10 & $3.2 \%$ & 92 & $29.6 \%$ \\
\hline Sports Turf & & 4 & $1.3 \%$ & 3.0 & 10 & $3.2 \%$ & 58 & $18.6 \%$ \\
\hline & Total & 20 & $6.4 \%$ & 3.8 & 39 & $12.5 \%$ & 252 & $81.0 \%$ \\
\hline
\end{tabular}

\section{Desired Product Characteristics}

Arguably the most essential, and frequently the most difficult, marketing function is to determine what consumers want out of a product or service. Stated differently, product suppliers should strive to match the characteristics of the product with buyer expectations. The closer the match, the more satisfied the customer, and the greater value attached to the product. If a producer succeeds in providing the features desired by the customer, it should translate into greater perceived value, which in turn should result in higher prices and greater quantities sold. To assess buyer expectations regarding sod, two questions were asked. First, what are the most important criteria you consider when purchasing sod? Second, what features or product characteristics do you like most about sod? Respondents were also requested to rank options on a scale of one to three with one being the most important. Results, presented in Table 9, are weighted averages for all firms and are also categorized by type of business. Weighted averages are calculated by multiplying the number of responses at each of the three rankings by the number of points for that ranking (i.e. rank $1=1 \mathrm{pt}$; rank $2=2$ pts.; and rank $3=3$ pts.) then adding the three totals together and dividing them by the total number of respondents. In this situation, the lower the average number, the more important the factor to the respondents. 
Table 9. Weighted averages of respondents' rankings regarding the importance of various purchasing criteria and features liked most about sod, U.S. Western data, 2001. (Ranked on a scale of 1 to 3 , with " 1 " being most important.)

\begin{tabular}{|c|c|c|c|c|c|}
\hline Major Sod Features & Contractor & $\begin{array}{c}\text { Landscape } \\
\text { Services }\end{array}$ & Retailer & $\begin{array}{l}\text { Sports } \\
\text { Turf }\end{array}$ & All Firms \\
\hline \multicolumn{6}{|l|}{ 1. Purchasing Criteria } \\
\hline Quality & 1.94 & 1.36 & 1.32 & 1.35 & 1.38 \\
\hline Price & 1.72 & 2.26 & 2.39 & 2.17 & 2.24 \\
\hline Availability & 2.15 & 2.15 & 2.20 & 2.32 & 2.21 \\
\hline Delivery & 2.50 & 2.59 & 2.69 & 2.78 & 2.66 \\
\hline \multicolumn{6}{|c|}{ 2. Features Liked Most about Sod } \\
\hline Rapid Establishment & 1.31 & 1.56 & 1.45 & 1.35 & 1.45 \\
\hline Attractive Appearance & 1.89 & 1.79 & 1.79 & 2.00 & 1.84 \\
\hline Erosion Control & 2.50 & 2.43 & 2.73 & 2.40 & 2.52 \\
\hline Weed Control & 2.75 & 2.58 & 2.60 & 2.69 & 2.62 \\
\hline
\end{tabular}

Purchasing Criteria. Consistent with the two earlier studies, quality was the most important purchasing criterion cited, as indicated by an average value of 1.38 for all firms (far right hand column, Table 9). The second most important feature across all firms was availability, with a weighted value of 2.21 , followed closely by price (2.24) and lastly by delivery with a value of 2.66. The reader should note that, because these tabulations are weighted, even small differences between values can be significant. For example, the variation between quality and price is notable since, on average, price is roughly half the value of quality. Obtaining high quality is deemed so important to buyers because the consequences resulting from a lack of quality are so serious. This is discussed further in the next section.

Examining results across buyer categories, little variation surfaced with the exception of contractors. Contractors were the only group to rank price (1.72) as the number one purchasing criteria, and it was much higher than the average (2.24). Quality was ranked second (1.94) for contractors, but again it varied considerably from the rest of the group, which gave it an average value of 1.38. With the remaining two attributes (availability and delivery), contractors were much more in line with the other buyer groups. Based on these results, western producers should treat the contractor market differently from other buyer groups.

Features Liked Most about Sod. In the western U.S., rapid establishment was by far the most desired product feature with an average weighted rank of 1.45 for all firms. This finding was consistent across customer groups, with little variation existing among them. Attractive 
appearance was the second (1.84) most important feature liked about sod. In the open-ended comments at the end, respondents noted that these first two attributes gave a completed look to their work, whether it was a residential unit, a sports athletic field, or a golf course. Until the sod was laid, the site lacked the finished, professional look that such businesses rely on. Erosion control was valued considerably less (2.52) than the first two attributes, with only about one-third the weighted value. Although still ranked third, buyer groups in the eastern U.S. applied more significance to erosion control. In fact, contractors in the east ranked it second, and not too far behind rapid establishment. Conversely, contractors in the western region gave it only marginal (2.50) importance. This may indicate that erosion control regulations are more stringent and penalties more severe in the northeast compared to the west. From a marketing standpoint, it means that producers will have less leverage with this particular product feature compared to the first two. It also suggests that market niches open to producers in the east will be less available to western sod producers.

\section{Market Expansion Strategies}

As observed previously, it is in a producer's best interest to determine what buyers want or expect from their products, do their best to provide it, and then communicate their offering back to the consumer. Marketing should be viewed as a process (as opposed to an event) of communicating and negotiating among interested parties until an agreement has been reached. In addition to communicating with customers, the producer should be aware of the environment within which the firm operates. This is commonly done through a market analysis. All producers operate within a set of geographic boundaries and share this space with certain competitors. Market competition refers to the direct and indirect threats faced by the firm. Direct threats would include other sod producers as well as other grasses the firm does not produce. Indirect competition refers to alternative choices available to the firm's intended customers, such as using Xeriscape products instead of lawn, or even perhaps selecting drought-tolerant native bahiagrass over the more intensively managed St. Augustinegrass. A market analysis then is a study of the basic factors defining the market for the firm's product, and how the firm should position itself to take advantage of available opportunities. The factors would include:

- Geographical boundaries of the market

- Economic, environmental, and competitive factors influencing activity in the market

- Specific market niche(s) that the firm intends targeting, including characteristics that define these niches

- Sales potential for the identified market

- Other products or services that directly or indirectly compete with those of the firm

Everything depends on satisfying the customer. The strategy of "selling what you grow" must be replaced with "growing what you can sell." The problem is that traditionally growers are not well connected to their consumers. Growing a product is a farmer's primary concern, and selling it is usually a secondary issue. Unfortunately, this passive approach to marketing carries 
substantial risks, particularly during periods of slowing economic activity.

"The era of simply selling what you grow is nearly gone. Success tomorrow will require growing what the consumer wants, a fact-based selling and increased marketing sophistication."

Bruce Axtman, Marketing Consultant Perishables Group, Inc.

Fact-based selling is another term for doing your homework (i.e., conducting market research) and using the results of the inquiry to develop a marketing program. Ultimately, marketing must concentrate on two related objectives: 1) how to move more product and 2) how to add value to that product. Both objectives require a consumer-oriented approach to marketing. Since producers are further removed from the consumer than wholesale or retail firms, establishing working relationships with them can benefit all parties involved. Typically producers sell their sod to contractors, landscape services, retailers, and sports turf facilities but infrequently directly to the end-user. Sod producers should develop partnerships with their major customers to establish linkages to the final customer. If solidly constructed, these relationships can be conduits that transmit crucial market information back and forth from producer to consumer on a regular basis. The strategies discussed below are ideas that were gleaned from the personal interviews conducted early in the project and from results obtained from the comprehensive telephone survey. The purpose is to provide practical ideas that may or may not be applicable to everyone.

Strategy 1. Identify unserved or under-served market niches.

Survey results showed that roughly 20 percent of the western market was being underserved. One-third of that 20 percent indicated that the problem was pervasive and ranked it a "four" on a one-to-five scale. Although this 20 percent may appear trivial, if this is projected to the entire western region turfgrass market, potential lost revenues could sum to many millions of dollars. Forgone economic opportunities of this magnitude are unacceptable for several reasons and they go beyond the losses attributable directly to the industry.

An un-served or under-served market also implies that customers unable to obtain turfgrass incurred additional expenses related to lost revenues. For instance, of the four categories identified, landscape service firms and general contractors were the most seriously affected. Since sod is one of the last items to be placed on a landscaping operation, these businesses had to respond accordingly, including absorbing the additional search costs to locate the sod, or possibly substitute seed for sod, and they were probably late completing the project. All three scenarios are unsatisfactory outcomes from the perspective of the landscaping firm and the customer. Consider the following:

- Additional search costs delay the project and erode profitability. A delayed project undermines the efficient utilization of resources required for jobs already contracted for downstream. If negative impacts are serious enough, it could jeopardize the professional reputation of the business, which in turn compromises the firm's ability to compete 
effectively in the marketplace. If this occurs too frequently, the firm's customer base is jeopardized as dissatisfied customers look elsewhere.

- Substituting seed for sod is unacceptable if the final customer (e.g. the homeowner or commercial business) wanted sod in the first place. This customer will have been forced to forgo sod's tangible benefits and wait many months for the seeded lawn to become established. Hence the cost of an un-served market has a "trickle-down" effect that multiplies with ever increasing damage to the industry and ultimately to their customers.

Aside from this obvious downside, an unserved or under-served market also represents an opportunity for someone willing to take advantage of it. Doing so and succeeding will require implementing the following procedures:

1. Determine where the unserved market is located

- Is it economically feasible?

- Based on your location, can the market be served reliably?

- Can a profit be made?

2. Identify who they are

- Which market segment(s) do they represent?

- How many are there?

- How large are they?

- Are they permanent or temporary?

3. Find out what they want

- Why have they been un-served?

- What product or service features do they want?

- Can you deliver that product and service?

- If not, can your firm adapt to meet the market's needs?

- Based on the size of the market, is it consistent with your firm's capacity?

4. Decide how best to deliver it

- Develop a strategy to serve the market

- Depending on market characteristics, the strategy may entail forming alliances with other turfgrass suppliers

- Suppliers can carve out their own particular niches, while simultaneously working together to satisfy the market

Strategy 2. Differentiate customer base according to economic return

Sod producers tend to treat customers uniformly, yet not all customers are equal in terms of the value they generate for the firm. Some customers contribute substantially more to the bottom 
line than others. Sod producers should examine their customer base periodically to assess its economic return to the firm. Accounts should be examined in terms of five main criteria average volume of purchases, average value of transactions, frequency of transactions (weekly, monthly semi-annually, etc), extent to which related value-added services are used, and the timeliness of remuneration for services rendered. Based on these criteria, accounts should be grouped into low, medium, and high-valued customers.

Low-return customers should be scrutinized carefully to determine whether or not these customers are worth keeping. Typically, this group of customers are classified as "transactional buyers". Transactional buyers are primarily price driven and place little value on business relationships and information. As a consequence, they also exhibit little business loyalty and will purchase from competitors readily and frequently. Such customers can be costly to the firm, especially if considerable expenses were incurred acquiring their business in the first place through advertising and promotion.

Medium-valued customers should be examined to determine why their business activity is "lukewarm". This group requires careful study because it represents a potential opportunity. Is the producer doing something wrong in terms of the product and service he or she is providing? Might small changes in quality, price, or delivery result in significant improvements in the frequency and value of transactions? Customers in this category are oftentimes situated near a critical market threshold and simply need a nudge to move them in the right direction. For instance, this research discovered that educational needs of nearly all customer groups is substantial. The perception is that sod is expensive, requires excessive and frequent use of inputs such as fertilizers and chemicals, and is a high-water consumer. As a consequence, turfgrass-sod is an easy target for environmental groups who insist it is an environmental hazard. These allegations should be systematically, aggressively, and objectively addressed using good science. Turfgrass Producers International (TPI), for example, has numerous high-quality articles and fact sheets on dozens of topics available to producer members that should be used to educate the public. Consider the breadth and depth of educational materials available from TPI:

- Xeriscapes Using More, Not Less Water

- Stop Erosion Problems with Turfgrass-Sod

- Creating a Low Maintenance Lawn

- Fate of Turfgrass Pesticides - Key Concepts and Scientific Findings

- Myth Busting: Is Turfgrass a Wasteful Water Hog?

- Myth Busting: Are Lawns a Waste of Time and Money?

- A Value-Added Commodity from Dormant Seed to a Living Carpet

- The Role of Turfgrasses in Environmental Protection and Their Benefits to Humans

Sod producers should take advantage of this information for their individual and collective use. Individual growers must become proactive to meet this need head-on, particularly within their own market segment. Waiting for the "industry" to meet this challenge is a passive approach that leads to nowhere. Finally, it can be used as a marketing tool to nudge this middle 
group into a higher, value-added category for your business.

High-valued customers must also be identified and examined. Who are they? What patterns emerge in terms of the types of businesses they represent and the products and services they value most? Does your firm currently meet their expectations? How do you know it does? Astute producers should recognize that it is certainly in their best interest to find out. Let's look a little closer at this group.

High-valued customers can generally be labeled as "partnership buyers", meaning that they place considerable value on relationships and information (Whiteley and Hessan, 1997). Partnership buyers desire a proactive approach from their supplier, someone who will educate and inform, and who understands their company's needs. People in this group want a personalized approach to selling — one that is dependable, has mutually beneficial goals, and instills a sense of risk-sharing. This latter characteristic sends a powerful message that your firm is a reliable supplier that believes in standing behind its product. Wal-Mart, the retail giant, has developed such relationships with all of its major suppliers.

A special program should be developed for a company's best customers. The first step is to understand clearly what these customers want most, including what is currently working or not working for them in your product/service offerings. This necessitates obtaining an in-depth understanding of their current situation. Customers often have difficulty doing this, but with regular contact, useful insights can be gleaned and put to use. Communication devices can include phone calls, e-mails, faxes, or perhaps a newsletter. Although it requires more effort, a personalized approach to business dealings remains one of the most effective marketing tools today. A more formal and in-depth procedure to gather information on customer satisfaction is to conduct a short survey. Ideally the survey should accompany or immediately follow all major transactions. Data obtained from the survey should be compiled and reviewed regularly to monitor changes in customer needs or expectations and to reveal how successfully you have satisfied your business obligations.

Strategy 3. Commit to a branded way of interacting with customers.

A common misconception is that sod is a homogeneous product. In other words, sod is sod is sod. Nothing should be further from the truth. Although this misunderstanding can occur with both customers and producers, the consequences are far more severe when they arise from the latter. The reason it is so serious from a business perspective is that it breaks a fundamental rule when operating in a competitive environment. Within a competitive environment, a critical strategy is to somehow differentiate the product or service being offered. Successful managers ask themselves the Critical Marketing Question (CMQ), why should customers buy from me? What am I offering that is different, better, and has more value than my competitors? This should transcend the product itself and extend to the other features and benefits the product provides - guarantees, financial benefits, environmental properties, and aesthetic qualities. The set of benefits and features represents the total offering. Each company has the ability to finetune this package to meet the needs of the market being served and to distinguish itself from the competition - this is the art of brand building. As Philip Kotler states so succinctly: 
"When something is not a brand, it will

probably be viewed as a commodity. Then price is

what counts. When price is the only thing that

counts, the only winner is the low-cost producer."

Kotler, p. 63.

Any business striving to differentiate itself needs to look closely at what it stands for. First of all, just having a brand name is not enough. What does the brand name mean? What message is it trying to convey? What degree of preference does it create? If it is only a brand name, then it fails as a brand. Answering the following questions are essential to developing an effective brand name that represents your company. This exercise is especially critical for sod producers who can easily fall into the fatal trap of complacency with the view: "After all, I'm only producing sod."

- What will your firm commit to? (mission statement)

- What should your brand/personality be?

- What do customers value?

- What niche do you want to serve and commit to?

- What strategy will you develop for doing so?

- How long will it take to implement?

This last question relies on how well the first ones were answered and how close your business already is to offering a quality, branded product. The point is, your perception of what is being offered may differ from the customer's, yet it is only theirs that matters. To discover a more objective view of your offering, map what you do from beginning to end with a flow-chart. The purpose is to determine where areas of value are created and, just as importantly, to identify areas of waste, or where improvements can be made. In other words, review what is being done, how it is being done, and how the process can be improved. Doing so entails a two-step process of examining production and marketing efficiencies: 1) identify all major stages in the production process, from land preparation through harvest and 2) identify all major stages in the marketing process, from initial customer contact to shipping of the product, to after-sale service. For both the production and marketing process, each step represents an opportunity to reduce waste and costs, to enhance product quality, to increase value for the customer and, ultimately, profitability to the firm and satisfaction to the customer. 


\section{References}

Axtman, Bruce. 2001. "Getting More from Retail Relationships: Forging Partnerships with Buyers." Harvester 37(2):25.

Haydu, J. J., J. L. Cisar and L. N. Satterthwaite. 2002. "An Economic and Agronomic Profile of Florida's Sod Industry in 2000.” Economics Information Report EIR 02-6, Food \& Resource Economics Department, Institute of Food \& Agricultural Sciences, University of Florida.

Haydu, John J. and Alan W. Hodges. 2000. "Market Expansion Strategies for Turfgrass Producers in the Eastern United States. Economic Information Report EI 00-2. Food \& Resource Economics Department, Institute of Food \& Agricultural Sciences, University of Florida.

Haydu, John J. and Alan W. Hodges. 2001. "Market Expansion Strategies for Turfgrass Producers in the Central United States. Economic Information Report EI 01-04. Food \& Resource Economics Department, Institute of Food \& Agricultural Sciences, University of Florida.

Kotler, Philip. 1999. Kotler on Marketing: How to Create, Win, and Dominate Markets. The Free Press, New York, 257 pp.

Whiteley, Richard and Diane Hessan. 1997. Customer Centered Growth: Five Proven Strategies for Building Competitive Advantage. Addison-Wesley Publishing Company, New York, $320 \mathrm{pp}$. 